\title{
Spacing of Memory in The Book of My Lives by Aleksandar Hemon*
}

\begin{abstract}
Durić Dejan, Spacing of Memory in The Book of My Lives by Aleksandar Hemon. "Poznańskie Studia Slawistyczne" 16. Poznań 2019. Publishing House of the Poznań Society for the Advancement of the Arts and Sciences, Adam Mickiewicz University, pp. 101-122. ISSN 2084-3011.

The paper examines the memoir The Book of My Lives by Bosnian-American writer Aleksandar Hemon. This non-fiction work explores the author's childhood in the capital of Bosnia and Herzegovina before the collapse of Yugoslavia, and then his exile experience in Canada and the United States after the outbreak of the war. Through the prism of memory, the book deals with the subject of exiles, uprootedness and efforts to start a new life in a new environment. Being an autobiographical record, The Book of My Lives lends itself to the examination of the issue of exile and memory issues, which is one of the two themes of this paper. The second concerns the understanding of the relationship between memory and space. The paper seeks to show how the spatial dimension is also important for the creation of memory because memories represent an essential factor for the transformation of abstract space into a particular place.
\end{abstract}

KeYwords: life-writing; exile; memory; space; place

The Book of My Lives (2013) is a non-fiction work by Bosnian-American writer Aleksandar Hemon. It is an autobiographically inflected work referring to the author's childhood in Sarajevo and his subsequent experience in exile in Chicago, caused by the conflict in Bosnia and Herzegovina in the early 1990s. The text is based on strategies of recollection designed to create an inventory of key moments outlining a life story and an era. The book is closely related to the memoir genre as the narrator is not focused only on himself, but provides a perspective and commentary on his time, cultural, political and social processes as well as the persons involved in

${ }^{*}$ This work has been fully supported-supported in part by Croatian Science Foundation under the project IP-2016-06-9548. 
them, accompanied with interpretations and evaluations. The aim is not to offer a historical and social fresco, but to examine how the nationalistic frenzy of the early 1990s in the area of former Yugoslavia influenced a number of human destinies ranging from his own to that of his family and loved ones and how their exile experience shaped them. Hemon's work also belongs to the vast body of texts known as life-writing. According to Sidonie Smith and Julia Warson life writing is "a general term for writing that takes life, one's own or another's, as its subject. Such writing can be biographical, novelistic, historical or explicitly self-referential and therefore autobiographical" (Smith, Warson, 2010, 4).

The Book of My Lives creates a more solid whole together with Hemon's first novel Nowhere Man (2002), which explores the concept of autobiographical prose and features the author's alter ego Jozef Pronek. This is achieved through a threefold prism of others. Three subjective narrators account different aspects of the protagonist's life: in Sarajevo in the 1980s, in Kiev in the early 1990s and the beginnings of political upheaval in the Soviet Union where he lived on a scholarship, and as an immigrant in the USA. The novel is characterized by its diversified spatiality, as it shows the protagonist's spatial displacement, as well as a wide time range, namely, the entire 20th century. The title Nowhere Man references a Beatles song, as does the title of the second segment of the novel, Yesterday. These song titles are important reference points as they point to the complex relationship of the past and the present, which is perceived through the prism of identity and further reinforced by spatial reflections. The spatial displacement points to the existential and identity displacement relating to the alienation of exile. In this regard, the novel explores the relationship of time, space and memory through the prism of global exile and migrant experiences, set against the backdrop of the war in Bosnia. This is all in line with the challenges of constructing a biography, as it is presented from the view-point of others, pointing to the social framework necessary to preserve identity, as well as memory. Hemon revisits the aforementioned themes from his first novel in this nonfiction work. The examination of identity, trauma, exile, memory and territoriality represents a crucial framework of the author's fiction and nonfiction works.

In contrast to the novel Nowhere Man, in which others narrate about the main protagonist, in The Book of My Lives the narrator speaks about 
himself and his experiences. This moves us into an experiential context in which recall and memory represent essential strategies for the conceptualization of a life story and an image of an era. Hemon's memoir utilizes structural and formal procedures to refer to recall and auto-analysis. The question of memory is closely related to the nature of exile and the rift which the exiled perceives between the rootedness of the past and the present, caught between rootlessness and efforts to fit into a new environment. Memory has its own temporal dimension because recalling a personal and/ or collective past always involves going back in time. The reconstruction of a life story relies on the sequencing of events that have defined the development of an individual and their life. However, it also includes a spatial dimension as personal memories or memories of events that have symbolic value for the individual and/or community are linked to specific places (cf. Assmann, 2011, 24). Therefore, in Hemon's work, the experiential matrix is compounded by the introduction of the spatial dimension. The relationship between the past and present, built around the framework of exile and memory, is spatialized, as is memory itself. This spatialization will be the focus of this paper. Spatial reference points mirror the temporal ones, so the relationship between the past and the present is mapped onto the binary relationship between Europe and the United States and between Sarajevo and Chicago. The realm of the past includes the section in Europe, which the narrator has had to leave by happenstance because of military conflicts, as well as a section of the North American experience, marked by numerous ills and problems of exile. The realm of the present includes the Chicago period of the contemporaneous narrative self, already adjusted to the new environment. I will examine the question of memory through the issue of exile, as well as the relationship of space as a wider and more abstract category and place as something which is existentially verified, personal, specific and based in memory.

The Book of My Lives shows features of two memoir touchstones in its narrative structure and the forming of the narrative function.

Hemon's text retains a conventional exterior narrative form that affirms linearity and follows chronology in order for the whole to suggest an idea of processuality with respect to a life trajectory and the events which 
directed and shaped it. The exterior framework consists of three stages: the childhood and life of the narrator before the war, the war and arrival to the United States, and life in Chicago after the war in Bosnia and Herzegovina has ended. Thus, the exterior level points to the change and development of the subject, as the structure is based on gradations in his experience. He refers not only to the people he was closely related to and the events in which he participated, but also to the socio-political context and political participants during the war in Bosnia and Herzegovina, as they caused disruption in the lives of thousands of people and impacted the narrators experience of exile.

Within this framework, the author effects formal deviations. Due to the constant interplay of the narrative present and past, the narrators digressions and (re)interpretations of past events, the text gives the impression of digression and fragmentation. Episodes, stories and events are sequenced in an arbitrary manner, not respecting chronology and succession, with no strong cause-and-consequence relationships between chapters. The work consists of a series of vignettes from the past, creating a mosaic of a life story. This is related to the nature of exile and the disconnected nature of identity: the subject balances the divide between the old and the new (the past and the present, Bosnia and Herzegovina and the United States). Therefore, the text gives the impression that it follows the existential state of the narrator. Linear chronological sequencing provides the reader with a clearer insight into the transformation of a narrator and/or character. A non-linear and fragmentary structure involves the reader more and requires an effort to connect the fragments into a complete life story, introducing the question why the narrator cannot or does not want to recount events in a straightforward and coherent manner. The experience of exile is traumatic, therefore, according to Cubitt, the issue is not so much in the forming of stressful or painful memories, but the fact that they cannot be narrated in a conventional manner (Cubitt, 2007, 108-109). Therefore, the testimonial paradigm (Saunders, 2008, 328) could be (as is the case in The Book of My Lives) related to the concept of traumatic memory when an individual, according to Brison, is faced with the feeling of disintegration of the self and the impossibility of establishing a time-line, due to issues in the past reinforcing an uncertainty in the future (Brison, 1999, 43). In Hemon's work, the issues of disintegration and the impossibility of 
establishing continuity are linked to the trauma of dealing with the cataclysm of war and the destruction of numerous human fates, as well as displacement from the current of one's own existence during exile and the efforts to adapt to a new culture and environment, which is foreign and inaccessible to the exiled person. An attempt to narrate a personal life story is also one of the ways of dealing with a traumatic memory, as well as an attempt to conceive one's own voice (Brison, 1999, 47). It is an attempt to take control of one's own life story.

The memoir is divided into sixteen chapters or episodes, covering various aspects of the narrator's life, starting in 1969 with the birth of his sister Kristina and ending in 2010 with the death of his daughter Isabel. Birth and death form the frame within which we follow a number of moments in a life: growing up in Sarajevo, exile to the United States, the relationship with parents and friends, the experience of the war in Sarajevo, putting down roots in Chicago. Each of the episodes is woven through with the narrator's reflections on characteristic social, historical and cultural currents of the given moment. In addition to the relationship between life and death, the book is framed by an examination of the experience of exile, as evidenced in the first chapter, The Lives of Others. This chapter is crucial to understanding the work as a whole, and I will return to it in a further chapter of my analysis. The introductory chapter provides context, points to spatial and temporal issues and signals their interrelationship: the realm of the past is closely related to space, while the realm of the present represents an attempt to incorporate the uprooted subject into the new North American environment. As I will examine further in the paper, in this process memory serves as a kind of connective tissue.

As the work is a memoir, the narration is structured in a manner that is specific, but characteristic of that genre. Because the memoirist recalls past events from the perspective of his mature self in the present, he is concurrently a part of those events, but also beyond them. The narrator is extradiegetic, as he tells his story from the perspective of the present, with a time delay, by recalling events and people who marked his life and time, resulting in retrospectively organized narrative. However, the narrator is also homodiegetic because he participates as a character in the events of the past or recounts stories about others that he has been told. The extradiegetic/homodiegetic point of view allows for comparisons. This is 
a fundamental narrative strategy in Hemon's memoir and is essential for highlighting the duality of experience, memory and exile through the relationship between "here and there" and "then and now". Comparison indicates the existence of different levels and layers of memory and personal recollections, making them complex, dynamic and productive. The past is regularly split in two, which is indicated by the structure of most chapters in the memoir. They often begin with a recollection of the past in Sarajevo, and end with a comparison to the situation in Chicago or with a point about how the people mentioned are living now or how they ended up. Antara argues that, in Said's conception, in addition to painful and traumatic experiences, exile can also have positive connotations because there is a possibility of diversifying experiences - the exiled person is always a part of at least two cultures, making their experience more complex and richer. They are more aware of the convergence of different cultures, can compare them and be open to new influences (Antara, 2016, 147). They also find themselves in a position that enables them to have a better perspective on the culture that they came from and to "open themselves up to the opportunities afforded by seeing through the gaze of an outsider and an outcast" (Antara, 2016, 147). In this way, Bosnia and Herzegovina and the United States, more specifically, Sarajevo and Chicago are not only put in comparison, but also in dialogue, which is important for relating memory and space through the narration of memory and rehabilitation of experience.

According to Edward Said, we are living in the age of exile, because our time is plagued by displacement, refuge, and large-scale migrations. Consequently, the twentieth century is a century of exile literature (Said, 2000, 174). For Said, there are two types of exile: real and metaphorical. The first refers to geographical displacement, while the other implies experiences of individuals who remain within their cultures, but deliberately assume the position of exiles and marginalists (Said, 1993, 116). I will be exploring exile in the concrete, physical and geographical context. According to Zeng, "exile in the previous literary criticism, has been mostly a geographical concept: it is a synonym of the uprooted experience of living abroad, away from one's motherland" (Zeng, 2010, 1). He also points out the cultural and psychological dimension of exile (Zeng, 2010, 1). Hemon's memoir is characterized 
by examinations of cultural and psychological phenomena. Because of the circumstances of war, the exiled subject cannot return to Bosnia and Herzegovina, He remains in the United States and must learn the cultural codes of his new environment in order to fit in and organize his daily existence. In his early days in Chicago he feels cultural rootlessness because he encounters new norms, values, economic system, cultural postulates, behaviors and interpersonal relations. The psychological dimension is manifested through nostalgic and sentimental references to Sarajevo and his past life, and consequent sense of derealization and loneliness. Since exile is a geographical concept and involves the process of displacement, its essential determinant is spatial. However, it also includes a temporal dimension that manifests itself through the actions of memory and reminiscence, as well as the tendency for nostalgic narratives, also related to its psychological dimension. The term nostalgia, according to Janelle L. Wilson, "typically conjures up images of a previous time when life was 'good' [...] While one's nostalgic memories may connote a pleasant or good time in the past, the fact that the individual is removed form that ideal situation can trigger sadness and a sense of loss" (Wilson J.L., 2005, 21-22). It both relates to place and time. What causes that desire are memories of social ties, familiarity, intimacy, the idea of rootedness, which is now absent.

The memoir opens with the significantly named chapter The Lives of Others, where the noun 'others' refers to the existential question of outsiders, the marginalized, refugees, that is, those who occupy a marginal position in the new environment. Therefore, it summarizes the overall context of exile and contextualizes the narrator's life story in relation to the space-time dyad woven in throughout the text. It also introduces the general themes expounded on by the author in the chapters to follow. This episode consists of seven short subheadings, whose titles are mostly in the form of questions, examining space, identity and the exile experience through the prism of memory. The first subheading, Who Is That?, opens in 1969 with the birth of his sister. The story of a boy who is jealous of his sister because he is deprived of the attention of his parents and community is the beginning of the narrative about the interplay of one's own story with the stories of others, as well as togetherness and empathy. It also introduces the context of memory. In this part, there is a kind of primal moment that establishes the subject of memory: 
The recollection of that sororicide attempt is the earliest memory in which I can observe myself from outside: what I see is me and my sister. Never again would I be alone in the world, never again would I have it exclusively for myself. Never again would my selfhood be a sovereign territory devoid of the presence of others (Hemon, 2013, 7).

The self is defined in relation to others, therefore to exist means to communicate and share experiences with others.

This question is further explored in the next subheading Who are we?, in which the focus shifts from the individual to the collective. The reader is introduced to the context of the exile experience through the story of the experiences of the narrator's parents who escaped from the war in Bosnia and Herzegovina to Canada. Through the examination of their inability to self-legitimize in the new community the focus is placed on the "unhealable rift forced between a human being and a native place, between the self and its true home" (Said, 2000, 173). The parents' story is a pretext for the analysis of the memoirist's exile experience, ironically examined through the Us vs. Them opposition based on differences and stereotypes. This explains the (im)possibility of swift integration into a new community and justifies drifting into nostalgic narratives. Said also points out this binary opposition, in which the latter occupy a marginalized position, accompanied by a feeling of not belonging (Said, 2000, 177). This is highlighted in the book through a reference to the narrator's accent which Americans immediately identify as foreign. Therefore, the rift postulated through the brief story about the parents' experiences, is elucidated on an individual level, where the complex of past and memory becomes a touchstone of identity: "home, homeland, place (of the mind) is, as Said insists, crucial to the construction of one's identity. But it exists not only as a determining but as a determined cultural location, as a space of memory that alters the identity of the person inhabiting, viewing, passing through, or writing about it" (Marrouchi, 2001, 161-162).

In the third subheading, Us Versus Them, the author explains how in Hamilton (Canada) his parents were overwhelmed by not belonging to any recognizable community, and how they often thoroughly examined the differences between themselves - the immigrants and the native population. This is counterpointed in the aforementioned chapter, Who Are We?, wherein the narrator examines the social concept of raja, characteristic for Sarajevo and defined as a group of people related to a part of the city, 
neighborhood or district in which they live. Raja represents a recognizable community in which an individual and his qualities are validated. It brings into relief the very things that the parents, as well as the narrator, are missing in the new environment, which is their people, closeness and intimacy. Therefore "exile is a solitude experienced outside the group: the deprivations felt at not being with others in the communal habitation" (Said, 2000, 177). Consequently, it also has an effect on personality changes:

The situation of immigration leads to a kind of self-othering as well. Displacement results in a tenuous relationship with the past, with the self that used to exist and operate in a different place, where the qualities that constituted us were in no need of negotiation. Immigration is an ontological crisis because you are forced to negotiate the conditions of your selfhood under perpetually changing existential circumstances (Hemon, 2013, 16-17).

Exile changes, it leads to a difficult relationship with the new environment and its inhabitants; there is a rift between the past and the present, memories and the new reality, the former and the new home. According to Zeng, "exile means estrangement from the origin - disjointedness, disparity, decentralization, and marginality" (Zeng, 2010, 33), which is felt by the narrator. However, Said broadens the topic. He feels it's too narrow to define exile as traumatic and painful because individuals or groups are completely cut off from their place of birth and can no longer access it. Contrary to that idea, he explains that "difficulty consists not simply in being forced to live away from home, but rather [...] in living with the many reminders that you are in exile" (Said, 1993, 114), which brings us back into the realm of memory and recall. That is why he talks about the existence of two spaces in the experience of the exiled. Exiled is bound to both through certain rituals, habits, actions, procedures, routines. In the new space, they are at odds with the memory of those patterns from the previous space: "thus both the new and the old environments are vivid, actual, occurring together contrapuntally" (Said, 2000, 186). Therefore, the concept of space and the spatialization of memory has an important function in this memoir, which will be discussed in the next chapter. This is best illustrated by the chapter Family Dining. It begins by evoking the experience of military service in Yugoslavia, which is characterized, among other things, by terrible food. This is then contrasted by a nostalgic reminiscence of family food preparation. Preparing 
and eating meals is a kind of ritual that points to intimacy and communion. In this chapter, it is an introduction to reminiscences of family gatherings and the preparation of borscht that Hemon's ancestors brought with them from Galicia to Bosnia and Herzegovina. Later, he searches for the perfect borscht in Chicago but cannot find it:

I was always missing at least one ingredient, not counting the mystery one. More important, there is nothing as pathetic as solitary borscht. Making borscht for myself helped me grasp the metaphysics of family meals - the food needs to be prepared on the low but steady fire of love and consumed in a ritual of indelible togetherness. The crucial ingredient of the perfect borscht is a large, hungry family (Hemon, 2013, 38).

Borscht, as a symbol of deficiency and incompleteness in exiled life, refers to the constant presence of reminiscence and the fact that something is lacking, a mysterious ingredient, impossible to find in the new environment because it is a feature of the past in Bosnia and Herzegovina and linked to people and relationships. The experience with borscht is closely related to Said's understanding of the duality of exile experience, the position 'in between', because it involves separation and displacement from the original place and an effort to fit into or adapt to the new environment (Said, 1993, 114). It also points to the fact that "the achievements of exile are permanently undermined by the loss of something left behind" (Said, 2000, 173). Thus, in the chapter Dog Lives, the narrator reminisces about the dog Mak, who, among other things, brings up empathy and caring for others during the bleak times of war. The dog eventually came to Canada with the narrator's parents. The narrator concludes that in the new environment, the dog was the only remnant of his former life, or a reminder of it (Hemon, 2013, 91), a concrete link between Canada and Bosnia.

When Zeng explores the concept of 'semiotics of exile', he considers it in literature on five levels, including signification, selfhood, narrative, time, and genre:

Reflected in the disjointedness of signification, it implies a deconstructive poetics with an absent center, floating signifier, simulacrum, and fragmentation [...] Disjointedness within self implies a divided self, multiple personalities, masks, and doppelgangers. The disjointedness within narrative privileges fragmented text and narrative irony. Disjointedness within time implies fractured time and collage of times, as well as plural, tangential sequence. In terms of genre, the semiotics of exile implies inability to belong or categorize, thus has the propensity of upsetting genre (Zeng, 2010, 2). 
We can note the above in Hemon's text. Throughout the story of the narrator and his parents, we can observe that exile is a state of dislocation and longing for stability and integration that is now missing. The memoir narrative structure is fragmentary and digressive and follows the pattern of the fragmented nature of exile itself. With regard to time and memory, since exile is inseparable from memory, there exists constant interplay between various points in the past and present. This is connected to the genre features of memoirs, but also the fact that, for the exiled person, memory suggests former existential completeness. Memory is a bulwark against the chaos and uncertainty of the new. The Book of My Lives is difficult to classify by genre because memoir elements are interlaced with autobiographical, and personal elements with societal. According to Said, the experience of exile is directed towards an attempt to create order (Said, 2000, 181). Therefore, Hemon's memoir can be perceived as a sort of systematization attempt. We should, however, also add space to Zeng's categories.

Zerubavel argues that memories are always located in a familiar reality, environment or place. For this reason, the spatial dimension acts as connective tissue between temporally remote aspects of the personal past (Zerubavel, 2003, 40-41). Thereby space becomes one of the key integrating factors of our life story, as it is connected to one or more locales. Space exists as a material fact, but it is also a result of social interactions: the relationships of individuals and groups with each other and with the space. It can also have a psychological dimension, especially when we are talking about memory and exile. Rothberg thus adds to the interpretation that "memory is the past made present" (Rothberg, 2009, 3-4). This statement is explained through two prisms: memory occurs because of certain needs imposed by the personal and/or social situation in the present, but it is also an active process (Rothberg, 2009, 3-4). The exile experience is based in memory and reminiscence. It is a process that involves the transformation of memories and the acquisition of new ones in the new environment. Both processes are located in a concrete space. Edward W. Soja points out that human activity is always localized in a geographically verified context, however, the relationship between human activity and space is always two-way because, while human activity changes the space, space 
also affects human behavior. Consequently, for Soja, there are numerous parameters that affect the relationship between man and space and the social construct of space: ${ }^{1}$ locations relate to each other differently, there are differences in distance and accessibility, they are shaped by social institutions and often involve hierarchically structured relationships (Soja, 1971, 3 ). These are different from region to region, as demonstrated by the exile experiences of the narrator. Therefore, adaptation to the new environment is conditioned by the learning of new codes and mores, while at the same time, memories of the old space remain vivid. The relationship between man and space also includes emotional and psychological factors. Soja stresses that man is a very territorial being (Soja, 1971, 19). This does not mean that territory is only a space of struggle, but also a place of intimacy, as well as a locus of memory, because an individual always localizes their memories in recognizable and existentially significant places. According to Soja, it has different functions, two of which are dominant: it is the foundation of identity and the feeling of belonging, but also the starting point for social interactions (Soja, 1971, 20). Exile experiences are different: the memoirist lacks an established identity and sense of affiliation, while his social interactions are hampered, as seen in the first chapter. Throughout the book, the narrator refers several times to playing soccer. ${ }^{2}$ As a motif, soccer relates to connections, as it is a team sport based on the cooperation of a number of players and their depending on each other. Soccer was played in Sarajevo, and later in Chicago, the narrator finds a 'team' that he plays with, composed partly of Americans and partly of immigrants which underscores cultural differences. Earlier, in the chapter My Prisoner, he says he had no one to watch World Cup matches with because none of his close friends were in Chicago (Hemon, 2013, 96), implicitly commenting on the differences between Sarajevo and Chicago related to human connections and solidarity.

${ }^{1}$ In Postmodern Geographies (1989), Soja postulates a thesis on socially constructed space: "socially-produced space is a created structure comparable to other social constructions" (Soja, 1989, 80). According to this theory, the organization of space has its own social framework, incentives and conditions, and although space may be fundamentally material, it is the result of shaping and organizing (Soja 1989: 80).

${ }^{2}$ The game motif recurs In The Lives of Grandmasters in the form of chess, connecting people, as well as Sarajevo and Chicago. 
Space is related to symbols that point to common affiliation, but there is also often an idea of separation - the territory is delimited so that others cannot infiltrate it (Soja, 1971, 19). Exile implies a kind of infiltration during which one territory is exchanged for another, one that the newcomer is not connected to through personal and collective memory. The aforementioned concept of raja suggests the issue of territoriality, but also integration and familiarity: creating intimacy and memories with people sharing a certain area. Raja is the agent that the narrator will miss and whose equivalent he will not be able to find in the new North American environment. In different contexts, space takes on a different meaning; for the mature narrator it is the cornerstone of reminiscence and memory. ${ }^{3}$

For this reason, I will introduce the distinction between space and place into my analysis. In his study Geocriticism (2011), Westphal poses the distinction between space as a conceptual category and place ${ }^{4}$ as verified, empirically existing and concrete, although he also concludes that the boundary between the two is porous and that they can be interchanged (Westphal, 2011, 5). This is in line with Lefebvre's distinction between absolute space and social space, whereby the first term points to the totality of spatial dimensions, and the second to the fact that space cannot be conceived as a natural given because it is always a result of social, cultural, political, historical and personal processes (Lefebvre, 1991). According to this interpretation, abstract space can be concretized into places:

After all, a place is only a place because of the ways in which we, individually and collectively, organize space in such a way as to mark the topos as special, to set it apart from the spaces surrounding and infusing it. Our understanding of a particular place is determined by our personal experiences with it, but also by our reading about others' experiences, by our point of view, including our biases and our wishful thinking (Tally, 2011, ix-x).

${ }^{3}$ Spaces are related to memory because they preserve and trigger it, as pointed out by notable memory theorists such as Jan Assmann and Maurice Halbwachs (Assmann, 2011; Halbwachs, 1980, cf. Durić, 2018).

${ }^{4}$ According to Pultz Moslund, "there are numerous approaches to the study of place in literature - place as mapped by discourses and power; place as a transplatial contact zone; place as a dynamic process or event; place as emotional, imagined, remembered, or experienced by the senses" (Pultz Moslund, 2011, 30).

${ }^{5}$ Westphal invokes Flavio Schiava and his premise that space represents the context within which a meaningful place is realized, as well as Maria de Fantis, according to whom individual and collective values belonging to a space make it into a place (Westphal, 2011, 5). 
In The Book of My Lives, the themes of exile and memory are reflected in the relationship between place and space, which is depicted in the memoir in the relationship between Sarajevo and Chicago. The first city is an object of memory, while the second is the setting for the exile experience. Therefore, the alienation of the latter manifests through the spatial dichotomy constructed around the topos of the memory. The Lives of a Flaneur and Reasons Why I Do Not Wish to Leave Chicago: An Incomplete, Random List are two chapters important for understanding the relationship between space and place. These chapters put the two cities into direct comparison and show the slow process of assimilation from an exiled person into an integrated citizen. The Lives of a Flaneur, with regards to the theme of space and the localization of memory, contrasts the two flaneurs of through the prism of the past and the present. One of them is linked to Chicago and the other to Sarajevo, and the observation of changes in these cities is connected to the interior changes of the flaneur. Discussing space and flaneurism, Tally concludes that mobility allows the observer to simultaneously observe different influences that shape the city, and these are best identified through studying the behavior and activities of urban populations: "demographic knowledge is nearly as crucial as geographic knowledge, and the mobile psychology of metropolitan populations" (Tally, 2013, 96).

Sarajevo is the city where the narrator grew up, was formed as a person, had certain experiences, built his personal and social life. He is connected to Sarajevo through people and events, therefore also experiences and memories. Chicago is the city in which the exiled person is a newcomer and must create a network of relationships and people, a set of memories that would help him feel a sense of belonging and connection to the space. Sarajevo and the concept of raja are contrasted by the impersonal, individualistic way of life in Chicago. In the beginning, the two cities are different for the narrator in the way which he perceives them. However, the relationship between Sarajevo and Chicago is not only related to Hemon's attitudes and feelings, but also to the appearance of the space, the architecture and mentality of its inhabitants. The spatial determinants of the urban environment thus largely determine and direct the behaviors of the inhabitants, mirror their norms and values, ways of interaction, worldviews, shared practices, mentalities, shared behaviors and habits. Therefore, the 
contrast between the two cities lies in inclusion and exclusion, and, as we will see, this fundamental difference is already innate for the memoirist in their different urban planning.

The narrator first experiences Chicago as an underpaid interviewer for Greenpeace and gradually gets to know the city through spatial displacement. It is a moving point of view that enables observation, comparison and synthesis. The whole city is made up of fragments, so the formation of the urban topography is akin to connecting life episodes into a memoir. It is an effort to create the semblance of completeness and coherence, lost or disturbed through experiencing exile. Merging with the city becomes an existential necessity:

I became acquainted with Chicago, but I didn't know the city. The need to know it in my body, to locate myself in the world, wasn't satisfied; I was metaphysically ailing, because I didn't yet know how to be in Chicago. The American city was organized fundamentally differently from Sarajevo (Hemon, 2013, 116).

In other words, it is easier to get to know the exterior dimension of a city: it's parts and socio-economic and cultural relationships between them, landmarks and similar features, but this does not mean that we know the city "inside-out," that we are integrated in it, that it is a close relationship. In the beginning, Chicago does not provide the same thing that Sarajevo did - a geography of the soul (Hemon 2013, 88). The first level of "communication" with Chicago is to get acquainted from an external perspective - through observation. It is always double: walking gives an impression and experience of the city from an external perspective - the layout of streets, squares and buildings, sights, communal spaces and infrastructure. However, one also interacts with the space and the people who inhabit it, thereby learning their norms and values, and adopting behaviors in the new environment. Therefore, the next degree of relationship would be blending with the space.

The American city is undoubtedly quite different from the Bosnian, primarily because it is very impersonal, like most urban centers in the United States, probably due to the American lifestyle: the culture of capitalism and individuality. ${ }^{6}$ That is why the narrator suggests that Chicago's urban

\footnotetext{
${ }^{6}$ Chicago is what Soja calls a postmetropolis (Soja, 2005).
} 
architecture operates on the basis of separation and anonymity. The narrator's remark as he comes back from the airport to Chicago after returning from Sarajevo in 1997 reveals his perception of the city's character: unlike "small" Sarajevo, he notes the expansiveness of Chicago. However, the adjective "enormous" is followed by the adjective "distant", suggesting two facts: the mentality of the city encourages emotional distance, and its size conditions looser human interactions and relationships. The compact but fragmented structure of Sarajevo is counterpointed to the geometric orderliness of Chicago (Hemon, 2103, 114). It turns out that fundamental differences are ingrained in the urban planning and layout of cities:

Your sense of who you were, your deepest identity, was determined by your position in a human network, whose physical corollary was the architecture of the city. Chicago, on the other hand, was built not for people to come together but for them to be safely apart. Size, power, and the need for privacy seemed to be the dominant dimensions of its architecture. [...] In this city, I had no human network within which I could place myself; my Sarajevo, the city that had existed inside me and was still there, was subject to siege and destruction. My displacement was metaphysical to the precisely same extent to which it was physical. But I couldn't live nowhere (Hemon, 2103, 118).

Sarajevo is spatially and socially structured in such a way that it is characterized by tight associations between people - interaction is desirable, anonymity and privacy reduced, the concept of collective memory plays a big part in everyday life and interpersonal relationships. It consists of familiar places, smells, tastes, but also people with whom the experiences are shared. That is why it is an intimate and familiar place, as the narrator puts it:

Sarajevo was - and still is - a small town, viscous with stories and history, brimming with people I knew and loved, all of whom I could monitor from a well-chosen kafana perch or by patrolling the streets (Hemon, 2013, 109).

Being a resident of Sarajevo means to be included in the collective memory of its inhabitants, which implies amalgamation with the city and its mythology. This is why the author states that, if someone disappeared, they could be reconstructed on the basis of collective memory, indicating interconnection and correlation. As Ferrar points out, specific locations are always linked to feelings or values and social relationships (Ferrar, 2005,106): 
In Sarajevo, you possessed a personal infrastructure: your kafana, your barber, your butcher; the streets where people recognized you, the space that identified you; the landmarks of your life (Hemon, 2013, 117).

Sarajevo is a place because it carries a strong personal and intimate mark and is identically authenticated, concrete, and offers lived experiences and human interactions.

In The Lives of a Flaneur, the narrator returns to Sarajevo after the war, which is a key moment for his integration on Chicago. The return is an occasion for a number of reminiscences about the past: the city, favorite places, people, social events, smells and tastes, walks, columns of Sarajevo republika that he wrote about urban features, intended to evoke the spirit of Sarajevo, urban mythology and speech. The time gap between the pre-war and post-war context leads to a dissociation of space:

Everything was fantastically different from what I'd known and everything was fantastically the same as before (Hemon, 2013 104-105).

I revisited all my favorite spots in the city center, then roamed the narrow streets high up in the hills [...]. I randomly entered building hallways and basements, just to smell them (Hemon, 2013, 105).

As a Bosnian in Chicago, I'd experienced one form of displacement, but this was another: I was displaced in a place that had been mine. In Sarajevo, everything around me was familiar to the point of pain and entirely uncanny and distant (Hemon, 2013, 105).

The narrator talks about two versions of homelessness: one is connected to Chicago where he was an exile and outsider and the other to Sarajevo because both he and the city have changed. According to Zerubavel "constancy of place is a formidable basis for establishing a strong sense of sameness. Even as we ourselves undergo dramatic changes both individually and collectively, our physical surroundings usually remain realtively stable" (Zerubavel, 2003, 41). This is why the narrator visits familiar locations and seeks out distinctive smells and tastes. However, space is a dynamic place prone to change: buildings are torn down and new ones are built, streets are transformed, the exteriors change, but the spirit, atmosphere and the inhabitants are also subject to change. However, Zerubavel's observation of stability is false, because in The Book of My Lives there is a threefold transformation: the city, the observer, and the observer's perception of the city. Therefore, "to return is not only a trip to a no-longerexisting past, but also involves an encounter with a nolonger-existing self" 
(Wilson E., 2005, 127), ${ }^{7}$ and this realization is crucial for the narrator. When he walks past the former cinema, he remembers watching the film Once Upon a Time in America, which is a symptomatic title given his return to Sarajevo and his former life (Hemon, 2013, 106): the city is not what it used to be for the flaneur. He started out to find what was recorded in memory, but there is an almost uncanny feeling: everything is simultaneously familiar, but also remote and foreign. ${ }^{8}$ According to Wilson:

To return to a city in which you used to live is - especially if the gap is a long one - to be made sharply aware of the passage of time, and the changing fabric of cities congeals that process of the passage of time in a way that is both concrete and somehow eerie or ghostly. It reminds you that a city is neither of those two favourite figures of speech: a work of art or a diseased organism. It is a process, an unique, ongoing time/space event (Wilson E., 2005, 126).

The digression about returning to Sarajevo is particularly significant because it leads the narrator to conclude that Sarajevo is now only an object of his memories and no longer necessarily his city, at least not as he knew it. The city and the narrator, as well as their stories, have gone down different paths, and Sarajevo became an object of memory.

According to Tuan, space and place are fundamental points in man's organization of his own existence, wherein space is transformed into place through the process of acquiring experience. Therefore, he concludes that an "object or place achieves concrete reality when our experience of it is total, that is, through all the senses as well as with the active and reflective mind" (Tuan, 1977, 18). Thus, the place we know from an inner perspective because it is experienced and lived, is existentially coalesced with us. A new space, as Chicago is for the narrator, is experienced externally from the perspective of a stranger or observer who has nothing in common with the city: he does not have private or social bonds to it and no memories of it. This is why the longing for Sarajevo is aroused by the memory of social ties, familiarity, intimacy, the idea of rootedness. Tuan coined the

${ }^{7}$ Wilson perceives the city as a kind of palimpsest because it is exposed to constant change during which new urban layers are created. They cover the old, which still remain in the background: "the notion of change is central to the experience of modern and contemporary urban life" (Wilson E., 2005, 127).

${ }^{8}$ Ryoko Wakamiya points out that exile stories are often associated with stories of return, regularly imbued with estrangement (Ryoko Wakamiya, 2009, 1-2). 
term topophilia, signifying an "affective bond between people and place or setting" (Tuan, 1990, 4), constituting the totality of relationships, especially between tangible nature, man and his spatial environment (Tuan, 1990, 93), as well as noting familiarity with and awareness of the past, that is to say, recollection and memories (Tuan, 1990, 99). Therefore, according to him, a place is made up of human relationships, everyday events and rituals, intimate locations and ordinary objects (Tuan, 1990, 140, 143, 144). The moving perspective of the flaneur eventually enables the subject to recognize the specifics of the new city - Chicago, that is, to try to penetrate into its interior, starting with moving to the Edgewater district:

I discovered that the process of transforming an American city into a space you could call your own required starting in a particular neighborhood (Hemon, 2013, 124).

Showing Veba around, telling him the stories of Chicago and of my life in Edgewater, I realized that my immigrant interior had begun to merge with the American exterior [...]When I came back from my first visit to Sarajevo, in the spring of 1997, the Chicago I came back to belonged to me. Returning from home, I returned home (Hemon, 2013, 126, 128).

Large parts of Chicago had entered me and settled there; I fully owned those parts now. I saw Chicago through the eyes of Sarajevo and the two cities now created a complicated internal landscape in which stories could be generated (Hemon, 2013, 128).

This walking is similar to de Certeau's concept of a city walker who uses walking to explore and "write" the city, creating a whole from the parts (de Certeau, 2002, 157), whereby space is parallel to the process of expression in language (de Certeau, 2002, 162).

According to Tuan, we can talk about place only when we stop because it represents a stop in motion after we fill it with values (Tuan, 1977, 138). This demonstrates the creation of social relationships and interactions, memories, recollections and integration that transform space into a place. Central importance is therefore given to the chapter Reasons Why I Do Not Wish to Leave Chicago: An Incomplete, Random List in which the narrator talks about integrating in Chicago. The list cites exactly those subjective elements that bind us to a particular space, which are special and specific to us and which only we notice. We could explain this through Seamon's term at-homeness, which points to intimacy, familiarity, routines of our everyday life. Anything else is "visiting," "in transit," "not at home," "out of place" or "traveling" (Seamon, 2001, 40). 
The Book of My Lives by Aleksandar Hemon suggests that memoirs can serve a double function. As far as the author is concerned, they are an attempt to systematize one's own story by questioning its points of reference or traumatic events that have determined its course. Hemon's text is a confessional narrative, based on autobiographical memory and an attempt to (re)interpret events which have defined the narrator. Meanwhile, its primary function is explanatory: the narrator is trying to explain to himself and the readers how certain events from the past defined him and shaped the course of his life. The writing of one's life story and the complex of memories is closely related to the nature of exile, based on the interlacing of the temporal and spatial matrices. As we have noted, the spatial dimension of The Book of My Lives is extremely important because it points to the problem of the localization of memory. It does not function only in the temporal, but also spatial dimension. Our memories are related to certain locations, people, situations and related events. It is precisely the relationship between space and memory that is crucial in the moments of migration and exile when individuals are forced to leave their home and move to new and unfamiliar areas with which they are not related to through memories. This paper demonstrates how the concept of space turns into the concept of place - by becoming familiar. The question is how do we become familiar with it? The Book of My Lives demonstrates how space becomes place when an individual starts to associate with it his or her own memories, people, social interactions, intimate relationships and experiences.

\section{References}

Antara, A. (2016). Edward Said and Exile: A Gaze at Counterpoint. "DEBATS: Annual Review" no. 1, pp. 145-149.

Assmann, J. (2011). Cultural Memory and Early Civilization: Writing, Remembrance, and Political Imagination. New York: Cambridge University Press.

Brison, S. (1999). Trauma Narratives and the Rethinking of the Self. In: Acts of Memory: Cultural Recall in the Present. Eds. M. Bal, J. Crewe, L. Spitzer, Hanover - London: Dartmouth College - University Press of New England, pp. 39-54.

de Certeau, M. (2002). Invencija svakodnevice. Transl. G. Popović. Zagreb: Naklada MD. 
Cubitt, G. (2007). History and memory. Manchester - New York: Manchester University Press.

Durić, D. (2018). Između književnosti i pamćenja: prisjećanje zaboravljenoga. Rijeka: Filozofski fakultet u Rijeci.

Farrar, M. (2005). Migrant Spaces and Settlers' Time: Forming and De-forming an Inner City. In: Imagining Cities: scripts, signs, memory. Eds. S. Westwood, J. Williams, London - New York, Routledge, pp. 103-121.

Halbwachs, M. (1980). The Collective Memory. New York: Harper Colophon Books.

Hemon, A. (2013). The Book of My Lives. New York: Picador.

Lefebvre, H. (1991). The Production of Space. Transl. D. Nicholson-Smith. Cambridge - Oxford: Blackwell Publishing.

Marrouchi, M. (2001). The Site of Memory. In: Edward Said and the Post-Colonial. Eds. B. Ashcroft, H. Kadhim, Huntington: Nova Science Publishers, inc., pp. 159-186.

Pultz Moslund, S. (2011). The Presencing of Place in Literature: Toward an Embodied Topopoetic Mode of Reading. In: Geocritical Explorations: Space, Place, and Mapping in Literary and Cultural Studies. Ed. R.T. Tally Jr., New York: Palgrave Macmillan, pp. 29-43.

Rothberg, M. (2009). Multidirectional Memory: Remembering the Holocaust in the Age of Decolonization. Stanford: Stanford University Press.

Ryoko Wakamiya, L. (2009). Locating Exiled Writers in Contemporary Russian Literature: Exiles at Home. New York: Palgrave Macmillan.

Said, E.W. (1993). Intellectual Exile: Expatriates and Marginals, "Grand Street" no. 47, pp. $112-124$.

Said, E.W. (2000). Reflections on Exile and the Other Essays. Cambridge: Harvard University Press.

Saunders, M. (2008). Life-Writing, Cultural Memory, and Literary Studies. In: Media and Cultural Memory. Eds. A. Erll, A. Nünning, Berlin - New York: Walter de Gruyter, pp. 321-331.

Seamon, D. (2001). A Geography of the Lifeworld: Movement, Rest and Encounter, Oxon - New York: Routledge.

Smith, S., Warson, J. (2010). Reading Autobiography: A Gudie for Interpreting Life Narratives. Minneapolis: University of Minnesota Press.

Soja, E.W. (1971). Political Organization of Space. Washington: Association of American Geographers.

Soja, E.W. (1989). Potsmodern Geographies: The Reassertion of Space in Critical Social Theory. London - New York: Verso.

Soja, E.W. (2005). Six Discourses on the Postmetropolis. In: Imagining Cities: Scripts, Signs, Nemory. Eds. S. Westwood, J. Williams, London - New York: Routledge, pp. 19-29.

Tally, R.T. (2013). Spatiality. London - New York: Routledge.

Tally, R.T. (2011). Translator's Preface: The Timely Emergence of Geocriticism. In: B. Westphal, Geocriticism: Real and Fictional Spaces. New York: Palgrave Macmillan, pp. ix-xiii. 
Tuan, Y.-F. (1977). Space and Place: The Perspective of Experience. Minneapolis: University of Minnesota Press.

Tuan, Y.-F. (1990). Topophilia: A Study of Environmental Perception, Attitudes, and Values. New York: Columbia University Press.

Westphal, B. (2011). Geocriticism: Real and Fictional Spaces. Transl. R.T. Tally. New York: Palgrave Macmillan.

Wilson, E. (2005). Looking Backward, Nostalgia and the City. In: Imagining Cities: Scripts, Signs, Memory. Eds. S. Westwood, J. Williams, London - New York: Routledge, pp. 125-136.

Wilson, J.L. (2005). Nostalgia: Sanctuary of Meaning. Lewisburg: Bucknell University Press.

Zeng, H. (2010). The Semiotics of Exile in Literature. New York: Palgrave Macmillan. Zerubavel, E. (2003). Time Maps: Collective Memory and the Social Shape of Past. Chicago - London: The University of Chicago Press. 